\title{
Microstructure characterization and hardness of Al-Cu-Mn eutectic alloy
}

Yusuf Kaygısız

Department of Electricity and Energy, Technical Vocational School of Sciences, Aksaray University, Aksaray, Turkey

\begin{abstract}
The composition of Al-Cu-Mn ternary eutectic alloy was chosen to be Al-32.5wt.\%Cu-0.6wt.\%Mn to the $\mathrm{Al}_{2} \mathrm{Cu}$ and $\mathrm{Al}_{12} \mathrm{CuMn}_{2}$ solid phases within an aluminum matrix ( $\alpha-\mathrm{Al}$ ) from its melt. The $\mathrm{Al}-32.5 \mathrm{wt} . \% \mathrm{Cu}-0.6 \mathrm{wt} . \% \mathrm{Mn}$ alloy was directionally solidified at a constant temperature gradient $\left(G=8.1 \mathrm{~K} \cdot \mathrm{mm}^{-1}\right)$ with different growth rates, 8.4 to $166.2 \mu \mathrm{m} \cdot \mathrm{s}^{-1}$, by using a Bridgman-type furnace. The eutectic temperature (the melting point) of $547.85{ }^{\circ} \mathrm{C}$ for the Al-32.5wt.\%Cu-0.6wt.\%Mn alloy was obtained from the DTA curve of the temperature difference between the test sample and the inert reference sample versus temperature or time. The lamellar spacings $(\lambda)$ were measured from transverse sections of the samples. The dependencies of lamellar spacings $\left(\lambda_{\mathrm{Al}-\mathrm{Al} 2 \mathrm{Cu}}\right)$ and microhardness on growth rates were obtained as, $\lambda_{\mathrm{Al}-\mathrm{Al} 2 \mathrm{C}}=3.02 \mathrm{~V}^{-0.36}, \mathrm{HV}=153.2(\mathrm{~V})^{0.035}, \mathrm{HV}=170.6(\lambda)^{-0.09}$ and $\mathrm{HV}=144.3+0.82\left(\lambda_{\mathrm{Al}}\right.$ $\left.\mathrm{Al}_{\mathrm{A} C \mathrm{Cu}}\right)^{-0.50}, \mathrm{HV}=149.9+53.48 \mathrm{~V}^{0.25}$, respectively, for the Al-Cu-Mn eutectic alloy. The bulk growth rates were determined as $\lambda_{\text {Al-Al2Cu }}^{2} \cdot V=25.38 \mu \mathrm{m}^{3} \cdot \mathrm{s}^{-1}$ by using the measured values of $\lambda_{\mathrm{Al}-\mathrm{Al} 2 \mathrm{Cu}}$ and $V$. A comparison of present results was also made with the previous similar experimental results.
\end{abstract}

Key words: directional solidification; aluminum alloys; microstructure; hardness test
CLC numbers: TG146.21
Document code: $\mathrm{A}$
Article ID: 1672-6421(2018 05-390-07

$\mathrm{S}$ olidification of industrial alloys generally proceeds through the formation of single phase primary crystals such as dendrites or poly-phase structures such as eutectics ${ }^{[1]}$. Eutectic alloys have a low melting point and excellent casting behavior ${ }^{[2]}$ and hence, casting alloys often have eutectic or near-eutectic composition. Directional solidification of eutectic alloys is a selfassembling procedure that allows fabricating from the melt fine homogeneous microstructures (eutectic spacings) controlled by the solidification parameters (temperature gradient and growth rate) ${ }^{[3]}$. Solidification behavior and microstructural characteristics of eutectic alloys in many systems continue to attract interest because of their influence on the properties and performance of materials containing eutectic constituents.

Aluminum alloys are produced and used in many forms such as casting, sheet, plate, bar, rod, channels and forgings in various areas of industry and especially in the aerospace industry. The advantages of these alloys over

\footnotetext{
*Yusuf Kaygisız

Male, born in 1982, Ph.D., Assistant Professor. His research interests mainly focus on the mechanical properties and characterization of metallic alloys. He has 10 published articles.

E-mail: yusufkaygisiz82@gmail.com

Received: 2017-10-30; Accepted: 2018-05-30
}

traditional iron-based alloys are light weight, corrosion resistance, and very good thermal and electrical conductivity. The 2XXX (Al-Cu-Mg) series aluminum alloys are commonly used in aircraft applications where high strength-to-weight ratios are required ${ }^{[4]}$.

The aim of this work is to experimentally investigate the effect of growth rates on the eutectic spacings $(\lambda)$ and microhardness in $\mathrm{Al}-32.5 \mathrm{wt} . \% \mathrm{Cu}-0.6 \mathrm{wt} . \% \mathrm{Mn}$ eutectic alloy and compare the results with the experimental system studied previously for Al-based binary or ternary eutectic alloys. Besides, the eutectic temperature (the melting point) for the $\mathrm{Al}-32.5 \mathrm{wt} . \% \mathrm{Cu}-$ $0.6 \mathrm{wt} . \% \mathrm{Mn}$ alloy was determined from the differential thermal analysis (DTA) curve.

\section{Experimental procedure}

The composition of Al-Cu-Mn ternary alloy was chosen to be Al-32.5wt.\% Cu-0.6wt.\% Mn to the eutectic phases from ternary liquid ${ }^{[5]}$. The Al-Cu-Mn molten alloy was prepared under vacuum by using 99.99\% pure aluminum, $99.99 \%$ pure copper and $99.98 \%$ pure manganese and poured into 7 graphite crucibles $(200 \mathrm{~mm}$ in length $4 \mathrm{~mm}$ ID and $6.35 \mathrm{~mm}$ OD), held in a specially constructed casting furnace (Hot Filling Furnace) at approximately $50{ }^{\circ} \mathrm{C}$ above the melting point of eutectic alloy. The molten alloy 
was directionally solidified from the bottom to top to ensure that the crucible was completely full. Then, each sample was positioned in a Bridgman type furnace within a graphite cylinder (300 mm in length $10 \mathrm{~mm}$ ID and $40 \mathrm{~mm}$ OD). Samples were directionally solidified at a constant temperature gradient $(G=8.1$ $\mathrm{K} \cdot \mathrm{mm}^{-1}$ ) with different pulling rates from 8.4 to $166.2 \mu \mathrm{m} \cdot \mathrm{s}^{-1}$ by using different speeded synchronous motors.

The quenched sample was removed from the graphite crucible and cut into lengths, typically $8 \mathrm{~mm}$. The longitudinal and transverse sections were ground flat with $\mathrm{SiC}$ paper and cold mounted with epoxy-resin. After the samples were etched with $6 \mathrm{ml}$ nitric acid $+2 \mathrm{ml}$ hydrofluoric acid $+92 \mathrm{ml}$ distilled water for $40 \mathrm{~s}$, the microstructures of samples were observed and photographed from both transverse and longitudinal sections with an Olympus DP12 digital camera placed in conjunction with an Olympus BHX type light optical microscope and a ZEISS Gemini 500 model field emission scanning electron microscopy (SEM). The quantitative chemical composition analyses of the phases were carried out by using an energy dispersive X-ray analyzer (EDX).
The Vickers hardness values of any solidified materials were obtained at a load of $100 \mathrm{~g}$ on the transverse cross-section by using a Fujitech FM-700 model hardness measuring test device. The microhardness was the average of at least 10 measurements on the transverse sections (HV).

Because of the important parameters for metallurgy applications, melting point (eutectic temperature) and solidification onset temperature of Al-32.5wt.\%Cu-0.6wt.\%Mn eutectic alloy were determined. The DTA (Exstar TG/DTA 7300 High Temperature Type model) thermal analysis was performed in the temperature range of $25-900{ }^{\circ} \mathrm{C}$ with a heating rate of 10 ${ }^{\circ} \mathrm{C} \cdot \min ^{-1}$ and under atmospheric pressure.

\section{Results and discussion}

\subsection{Microstructure observation and effect of growth rate on lamellar spacings}

Figure 1 shows optical micrographs of directionally solidified Al-32.5wt.\%Cu-0.6wt.\%Mn eutectic alloy for different growth

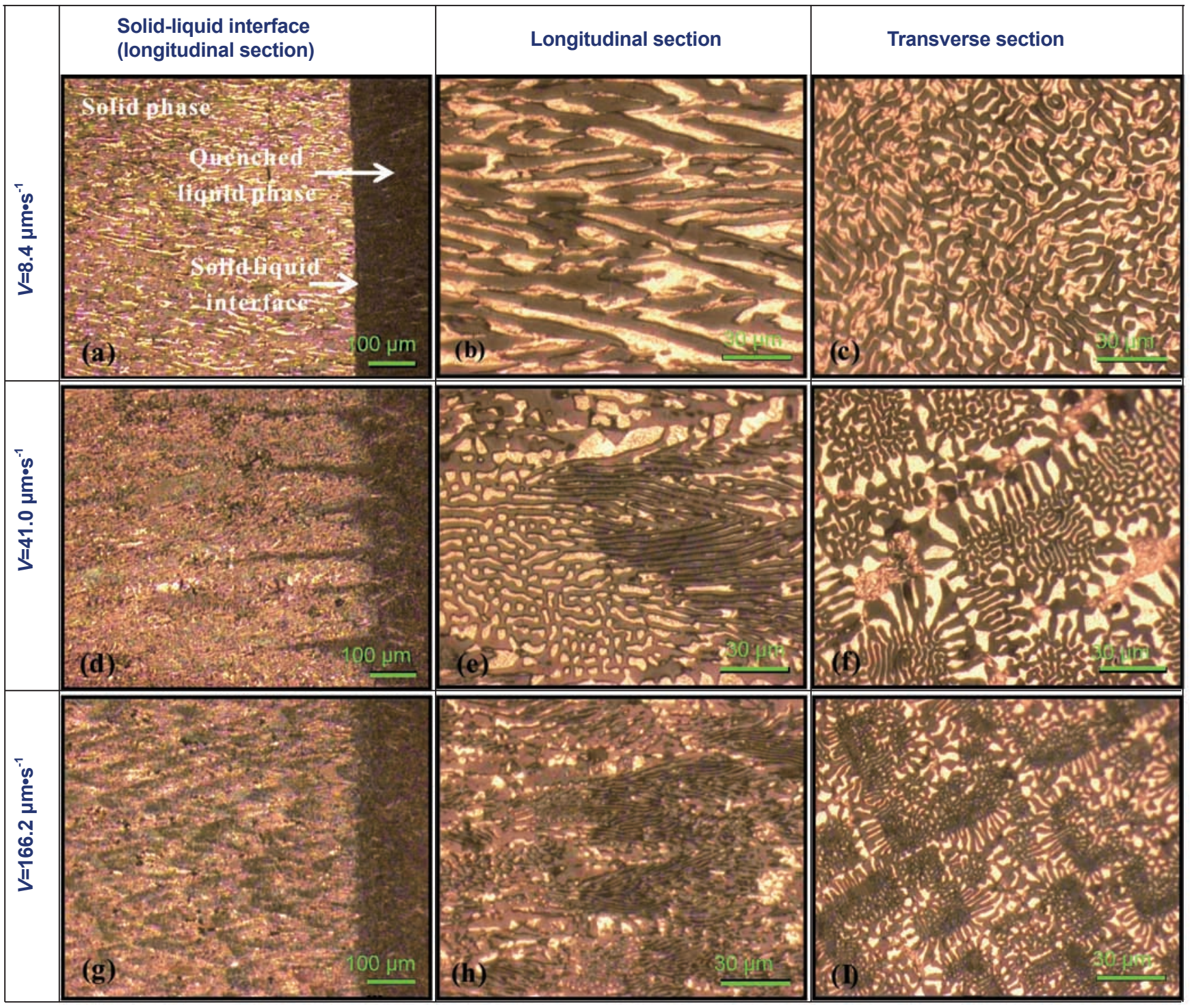

Fig. 1: Micrographs of directionally solidified Al-Cu-Mn eutectic alloy at different growth rates $\left(V=8.4-166.2 \mu m^{\circ} \mathrm{s}^{-1}\right)$ 
rates. As can be seen from Figs. 1(b) and (c), the $\mathrm{Al}-\mathrm{Al}_{2} \mathrm{Cu}$ binary eutectic lamellae structure was grown degenerate and $\mathrm{Al}_{12} \mathrm{CuMn}_{2}$ phase in the structure was observed to grow as scattered in the directionally solidified Al-Cu-Mn eutectic alloy at a low growth rate and constant temperature $\left(V=8.4 \mu \mathrm{m} \cdot \mathrm{s}^{-1}, G=8.1 \mathrm{~K} \cdot \mathrm{mm}^{-1}\right)$.

When the growth rate in the directionally solidified $\mathrm{Al}-\mathrm{Cu}-$ $\mathrm{Mn}$ eutectic alloy at a constant temperature was increased, the $\mathrm{Al}-\mathrm{Al}_{2} \mathrm{Cu}$ binary eutectic degenerate lamellae structure grew as colonies and the $\mathrm{Al}_{12} \mathrm{CuMn}_{2}$ phase in the structure concentrated at the boundary of the degenerated $\mathrm{Al}-\mathrm{Al}_{2} \mathrm{Cu}$ eutectic structure as shown in Fig. 1(c-f).

Also, the optical images of solid-liquid interface growth morphologies for directionally solidified Al-32.5wt.\% Cu0.6wt.\%Mn eutectic alloy are shown in Figs. 1(a), (d) and (g). During the unidirectional solidification process, the interface is planar for the directionally solidified Al-32.5wt.\%Cu-0.6wt.\%Mn eutectic alloy at a low growth rate $\left(V=8.4 \mu \mathrm{m} \cdot \mathrm{s}^{-1}\right)$, but solid-liquid interfaces are non-planar at the high growth rates $(V=41.0$ and $\left.166.2 \mu \mathrm{m} \cdot \mathrm{s}^{-1}\right)$.

The $\mathrm{Al}_{12} \mathrm{CuMn}_{2}$ phase at irregular structure in this reaction has a orthorhombic structure with lattice parameters $\mathrm{a}=2.411 \mathrm{~nm}, \mathrm{~b}=$ $1.251 \mathrm{~nm}$, and $\mathrm{c}=7.71 \mathrm{~nm}^{[6]}$. Its density is equal to $3.59 \mathrm{~g} \cdot \mathrm{cm}^{-3}{ }^{[7]}$.

The solid solubility of copper and manganese in solid aluminum are about $5.5 \mathrm{wt} . \%$ and $0.2 \mathrm{wt} . \%$, respectively, at the eutectic temperature of $547.5^{\circ} \mathrm{C}^{[8]}$

SEM images of directionally solidified Al-32.5wt.\%Cu0.6 wt.\%Mn eutectic alloy were also taken, as shown in Fig. 2. In the SEM images given in Fig. 2, $\mathrm{Al}$ and $\mathrm{Al}_{2} \mathrm{Cu}$ phases were observed but intermetallic $\mathrm{Al}_{12} \mathrm{CuMn}_{2}$ phase was not observed for directionally solidified $\mathrm{Al}-32.5 \mathrm{wt} . \% \mathrm{Cu}-0.6 \mathrm{wt} . \% \mathrm{Mn}$ eutectic alloy.

In the scanning electron microscope (SEM), the intensity of the signals of the backscattered electrons is strongly related to the atomic number of the sample. The reason why the $\mathrm{Al}_{12} \mathrm{CuMn}_{2}$ phase is not visible in the $\mathrm{Al}-32.5 \mathrm{wt} . \% \mathrm{Cu}-0.6 \mathrm{wt} . \% \mathrm{Mn}$ eutectic alloy system may be because the atomic numbers of copper and manganese elements are close and the amount of manganese element (0.6wt.\%) in the composition is very small.

The quantitative chemical composition analyses of phases in the sample were carried out by using EDX and the results are given in Fig. 2. According to the EDX results, white, and black phases were identified as $\mathrm{A}_{2} \mathrm{Cu}$ and $\alpha$-Al matrix, respectively.

The photographs of microstructures were taken from transverse and longitudinal sections of the samples and the measurements of eutectic spacing for $\mathrm{Al}-\mathrm{Al}_{2} \mathrm{Cu}$ binary eutectic phase were taken from at least in 10 regions near to the solid-liquid interface on the transverse section of each sample with a linear intercept method ${ }^{[9]}$.

As expected, the formations of the microstructures have varied with the growth rates at constant temperature gradients. As the growth rate is increased, the eutectic spacings decrease for all phases at a constant temperature gradient, as shown in Table 1. The highest eutectic spacing was obtained with the minimum growth rate value of $8.4 \mu \mathrm{m} \cdot \mathrm{s}^{-1}$ at a constant temperature gradient of $8.1 \mathrm{~K} \cdot \mathrm{mm}^{-1}$, as shown in Figs. 1(b) and (c). On the other hand, the smallest eutectic spacing was obtained with the maximum growth rate value of $166.2 \mu \mathrm{m} \cdot \mathrm{s}^{-1}$ at a constant temperature gradient of $8.1 \mathrm{~K} \cdot \mathrm{mm}^{-1}$, as shown in Figs. 1(h) and (i).

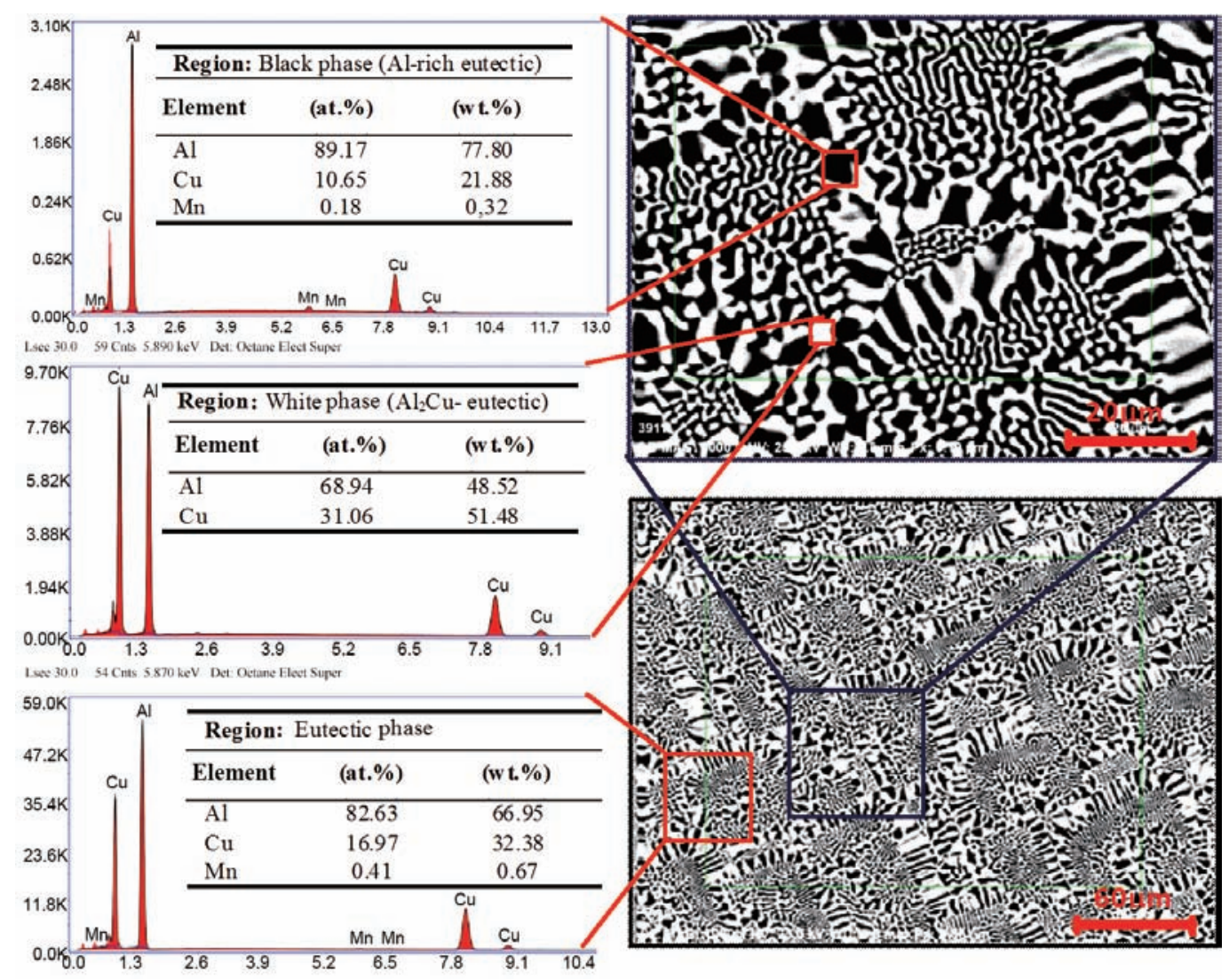

Fig. 2: Microstructure and chemical composition analysis of $\mathrm{Al}-32.5 \% \mathrm{Cu}-0.6 \% \mathrm{Mn}$ eutectic alloy by using SEM-EDX (transverse section, $V=41.7 \mu \mathrm{m} \cdot \mathrm{s}^{-1}$ ) 
Table 1: Variation of eutectic spacing $(\lambda)$ and microhardness (HV) with solidification parameters $(G, V)$ in directionally solidified Al-32.5wt.\%Cu-0.6wt.\%Mn eutectic alloy

\begin{tabular}{|c|c|c|c|c|}
\hline \multicolumn{2}{|c|}{ Solidification parameters } & \multirow{2}{*}{$\begin{array}{l}\text { Eutectic spacing } \\
\qquad \lambda(\mu \mathrm{m})\end{array}$} & \multirow{2}{*}{$\begin{array}{l}\text { Microhardness } \\
\text { HV }\left(\mathbf{k g} \cdot \mathbf{m m}^{-2}\right)\end{array}$} & \multirow{2}{*}{ Relationships } \\
\hline $\mathbf{G}\left(\mathbf{K} \cdot \mathbf{m m}^{-1}\right)$ & $V\left(\mu \mathrm{m} \cdot \mathrm{s}^{-1}\right)$ & & & \\
\hline \multirow{5}{*}{8.1} & 8.4 & $1.275 \pm 0.06$ & $164.7 \pm 1.2$ & $\lambda_{\mathrm{Al}-\mathrm{Al} 2 \mathrm{Cu}}=3.02 \mathrm{~V}^{-0.36}$ \\
\hline & 19.0 & $1.109 \pm 0.16$ & $169.0 \pm 1.3$ & $\mathrm{HV}=153.2(V)^{0.035}$ \\
\hline & 41.0 & $0.83 \pm 0.06$ & $178.0 \pm 1.4$ & $\mathrm{HV}=170.6(\lambda)^{-0.09}$ \\
\hline & 74.3 & $0.63 \pm 0.06$ & $177.0 \pm 1.5$ & $\mathrm{HV}=149.9+53.48(V)^{0.25}$ \\
\hline & 166.2 & $0.44 \pm 0.02$ & $183.0 \pm 1.0$ & $\mathrm{HV}=144.3+0.82\left(\lambda_{\mathrm{Al}-\mathrm{Al} 2 \mathrm{Cu}}\right)^{-0.50}$ \\
\hline
\end{tabular}

The measured values of lamellar spacings in the $\mathrm{Al}-\mathrm{Cu}-\mathrm{Mn}$ alloy as a function of growth rates at a constant temperature gradient are given in Fig. 3. A comparison of present results with the previous experimental results for Al-based alloys ${ }^{[10-12]}$ is also given in Fig. 3.

The variation of $\lambda$ versus $V$ is essentially linear on the logarithmic scale. As can be seen from Fig. 3, the data form straight lines. The linear regression analysis gives the proportionality equation for the constant temperature gradient $(G)$ as:

$$
\lambda=k_{1} V^{-n}
$$

where $k_{1}$ is a constant and $n$ is an exponent value of growth rate. The relationships between the eutectic spacings and growth rates were determined as $\lambda_{\mathrm{Al}-\mathrm{Al} 2 \mathrm{Cu}}=3.02 \mathrm{~V}^{0.36}$ by using linear regression analysis.

The exponent value of 0.36 relating to the growth rates for $\mathrm{Al}-\mathrm{A} 12 \mathrm{Cu}$ binary eutectic structure in the Al-Cu-Mn eutectic alloy obtained in this present work is very close to the exponent values of 0.35 and 0.39 relating to the growth rates in the Al$\mathrm{Cu}-\mathrm{Mg}, \mathrm{Al}-\mathrm{Cu}-\mathrm{Si}-\mathrm{Mg}$ and $\mathrm{Al}-\mathrm{Cu}$ eutectic alloys, respectively, as obtained in previous works ${ }^{[10-12]}$, but is greater than the exponent values of 0.27 and 0.29 relating to the growth rates in the Al$\mathrm{Cu}$ hypoeutectic alloy ${ }^{[13]}$ and is considerably smaller than the exponent value of 0.50 relating to the growth rates predicted by

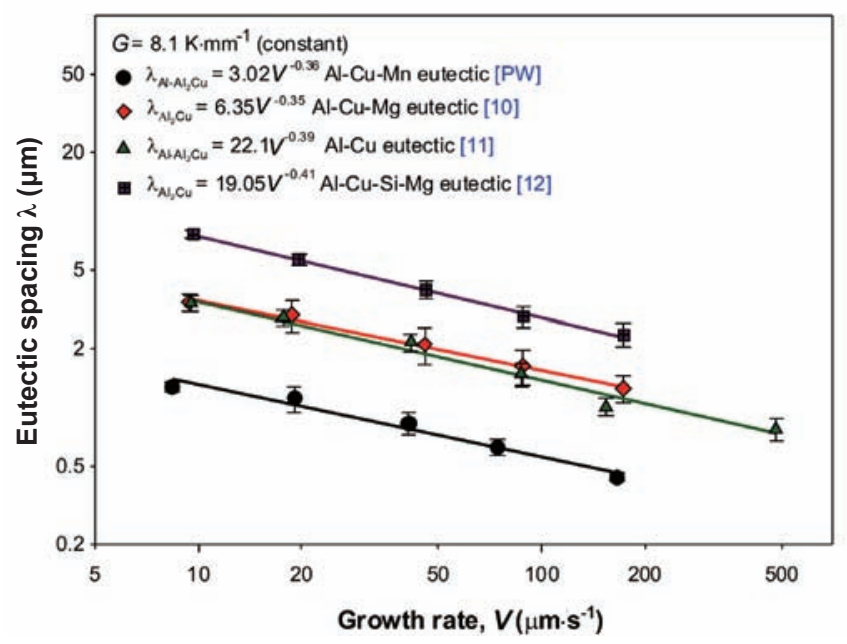

Fig. 3: Variations of eutectic spacings as a function of growth rates in Al-based binary and multicomponent eutectic alloys at a constant temperature gradient obtained in the present work and previous works
Jackson-Hunt eutectic theory ${ }^{[14]}$.

The correlation coefficient value of 3.02 relating to the growth rates for $\mathrm{Al}-\mathrm{Al}_{2} \mathrm{Cu}$ eutectic structure in the $\mathrm{Al}-\mathrm{Cu}-\mathrm{Mn}$ eutectic alloy obtained in the present work is about two times smaller than the exponent values of 6.35 relating to the growth rates for $\mathrm{Al}_{2} \mathrm{Cu}$ in the $\mathrm{Al}-\mathrm{Cu}-\mathrm{Mg}$ eutectic alloy obtained by previous work ${ }^{[10]}$ and seven times smaller than the exponent values of 19.05 and 22.1 relating to the growth rates for $\mathrm{Al}_{2} \mathrm{Cu}$ in the $\mathrm{Al}-\mathrm{Cu}-\mathrm{Si}$ $\mathrm{Mg}$ and $\mathrm{Al}-\mathrm{Cu}$ eutectic alloy obtained by previous work ${ }^{[11,12]}$. These disparities might be due to the existence of $\mathrm{Al}_{12} \mathrm{CuMn}_{2}$ intermetallic phase as an extra phase in the $\mathrm{Al}-\mathrm{Cu}-\mathrm{Mn}$ eutectic alloy.

The value of bulk growth rates for $\mathrm{Al}-\mathrm{Al}_{2} \mathrm{Cu}$ phase in the Al$\mathrm{Cu}-\mathrm{Mn}$ eutectic alloy was also found to be $\lambda_{\mathrm{Al}-\mathrm{Al} 2 \mathrm{C}} \cdot V=25.38$ $\mu \mathrm{m}^{3} \cdot \mathrm{s}^{-1}$ by using the measured values of $\lambda_{\mathrm{Al}-\mathrm{Al} 2 \mathrm{Cu}}$ and $V$. The

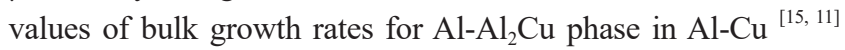
binary eutectic systems and for $\mathrm{Al}_{2} \mathrm{Cu}$ phase in $\mathrm{Al}-\mathrm{Cu}-\mathrm{Mg}{ }^{[10]}$ ternary eutectic system were found to be 108, 156 and 195.76 $\mu \mathrm{m}^{3} \cdot \mathrm{s}^{-1}$, respectively. The value of bulk growth rate of 25.38 $\mu \mathrm{m}^{3} \cdot \mathrm{s}^{-1}$ for $\mathrm{Al}-\mathrm{Al}_{2} \mathrm{Cu}$ phase in the eutectic $\mathrm{Al}-\mathrm{Cu}-\mathrm{Mn}$ system obtained in the present study is about four times smaller than the value of bulk growth rate, $108 \mu \mathrm{m}^{3} \cdot \mathrm{s}^{-1}$, for $\mathrm{Al}_{\alpha}-\mathrm{Al}_{2} \mathrm{Cu}$ lamellar in $\mathrm{Al}-\mathrm{Cu}$ eutectic system obtained by Burden and Jones ${ }^{[15]}$; is about six times smaller than the value of bulk growth rate, $156 \mathrm{~m}^{3} \cdot \mathrm{s}^{-1}$, for $\mathrm{Al}_{\alpha}-\mathrm{Al}_{2} \mathrm{Cu}$ lamellar in $\mathrm{Al}-\mathrm{Cu}$ eutectic system obtained by $\mathrm{E}$. Çadırlı et al. ${ }^{[11]}$; and is about eight times smaller than the value of bulk growth rate, $195.76 \mathrm{~m}^{3} \cdot \mathrm{s}^{-1}$, for $\mathrm{Al}_{2} \mathrm{Cu}$ phase in the $\mathrm{Al}-\mathrm{Cu}-\mathrm{Mg}$ eutectic alloy obtained by Y. Kaygısız and N. Maraşl1 ${ }^{[10]}$.

\subsection{Effect of growth rate on microhardness}

A dislocation which reaches a gain boundary cannot continue its slip motion into another grain because of the difference between orientation of the slip planes and directions between two neighboring grains. Hence, grain boundaries serve as obstacles to the movement of dislocations, which pile up near boundaries. Therefore, with decreasing grain size, less distance can be traveled by a glissile dislocation before reaching a grain boundary, resulting in higher strength. This strengthening mechanism is called grain size hardening ${ }^{[16]}$. Strengthening due to grain size effects can be described by the Hall-Petch ${ }^{[17,18]}$ equation :

$$
\sigma_{\mathrm{y}}=\sigma_{0}+k d^{-m}
$$

where, the exponent value of $m$ is 0.5 for grain size hardening. 
$\sigma_{0}$ and $k$ are the coefficients and affected by alloy content, grain size uniformity and shape as well as crystallographic texture. For example, the value of $\sigma_{0}$ is $10 \mathrm{MPa}$ for pure aluminum ${ }^{[19]}$, and increases with increasing alloy content. $k$ is 0.065 for pure aluminum $^{[20]}$.

In the present work, the lamellae distance $(\lambda)$ is related with the mean grain size and $\lambda$ is the proportional inverse the square root of growth rate $(V)$ according to the eutectic growth theory. Thus, the Hall-Petch type relationships between the microhardness and the microstructure spacing or growth rate can be expressed as follows:

$$
\begin{aligned}
& \mathrm{HV}=\mathrm{HV}_{0}+k_{2}(\lambda)^{-0.50} \\
& \mathrm{HV}=\mathrm{HV}_{0}+k_{3}(V)^{0.25}
\end{aligned}
$$

where $\mathrm{HV}_{0}$ is the initial microhardness of equilibrated solid phase with liquid at the melting temperature, $k_{2}$ and $k_{3}$ are constants which depend on kind of materials. The values of $\mathrm{HV}_{0}$, and $k_{2}$ and $k_{3}$ can be experimentally determined.

The variations of microhardness (HV) as a function of eutectic spacing $(\lambda)$ and growth rates $(V)$ at a constant temperature gradient $\left(\mathrm{G}=8.1 \mathrm{~K} \cdot \mathrm{mm}^{-1}\right)$ for $\mathrm{Al}-32.5 \mathrm{wt} . \% \mathrm{Cu}-0.6 \mathrm{wt} . \% \mathrm{Mn}$ eutectic alloy in the forms of Hall-Petch type and exponential were plotted in Fig. 4. Comparisons of present results with the previous experimental results for multicomponent eutectic alloys ${ }^{[10,12]}$ were also shown in Fig. 4.

The Hall-Petch type relationships between the microhardness and eutectic spacing and growth rate for directionally solidified
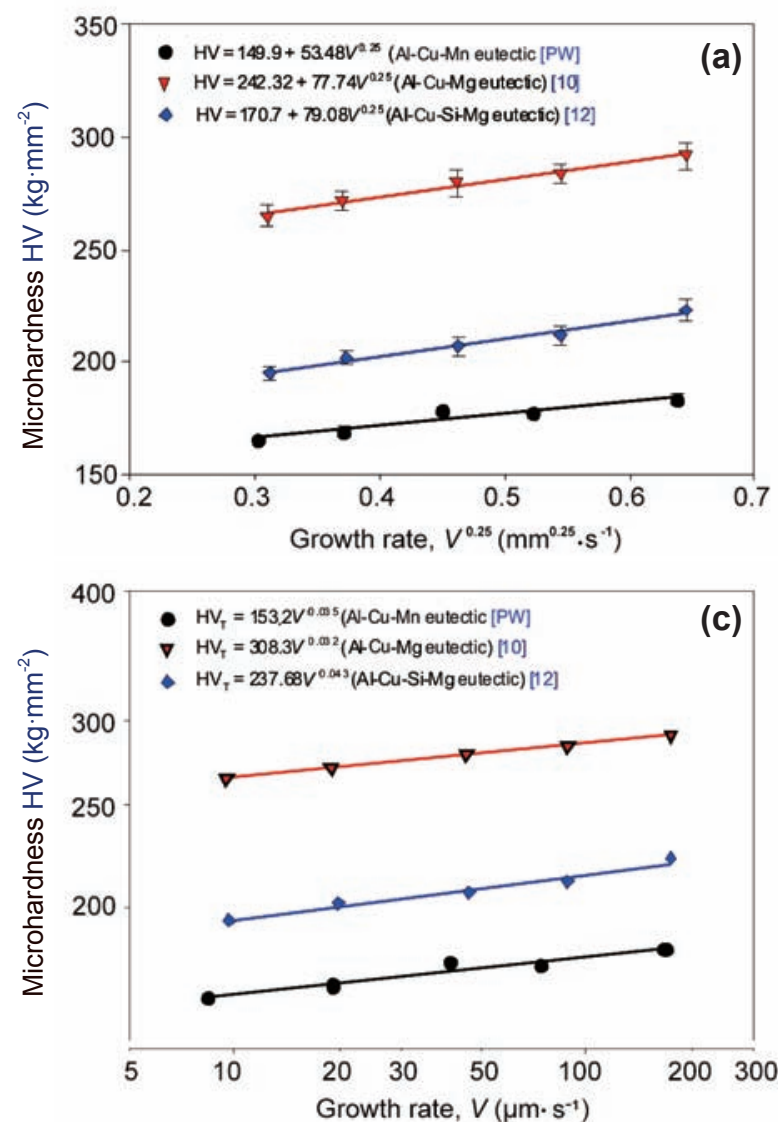

the $\mathrm{Al}-\mathrm{Cu}-\mathrm{Mn}$ eutectic alloy were obtained as:

$$
\begin{gathered}
\mathrm{HV}=144.3+0.82\left(\lambda_{\mathrm{Al}-\mathrm{Al} 2 \mathrm{Cu}}\right)^{-0.50} \\
\mathrm{HV}=149.9+53.48(V)^{0.25}
\end{gathered}
$$

As can be seen from Eqs. (5) and (6), the values of $\mathrm{HV}_{0}$ for eutectic spacings and growth rates are very close to each other's The values of 144.3 or $149.9 \mathrm{~kg} \cdot \mathrm{mm}^{-2}$ might be the initial microindentation hardness values for equilibrated solid eutectic phases in equilibrium with liquid in the $\mathrm{Al}-\mathrm{Cu}-\mathrm{Mn}$ eutectic alloy at its melting temperature and the values of $k_{2}=0.82$ and $k_{2}=53.48$ are the hardness against deformation with respect to eutectic spacings and growth rate for directionally solidified Al$\mathrm{Cu}-\mathrm{Mn}$ eutectic alloy. As can be seen from Eqs. (5) and (6), the initial micro indentation hardness value of 144.3 and 149.9 for $\mathrm{Al}-\mathrm{Cu}-\mathrm{Mn}$ eutectic alloy obtained in present work is close to the values of 170.7 and 163.4 for Al-Cu-Si-Mg alloy ${ }^{[12]}$, but is about twice the values of 65.77 and 65.37 for Al-Si-Mg ${ }^{[21]}$ alloy and is about $40 \%$ smaller than the value of 242.32 for $\mathrm{Al}-\mathrm{Cu}-\mathrm{Mg}{ }^{[10]}$ eutectic alloy. These disparities might be due to the difference of alloying elements $\mathrm{Cu}$ and $\mathrm{Mn}$ and the existence of $\mathrm{Al}_{12} \mathrm{CuMn}_{2}$ intermetallic phase as an extra phase in the Al-Cu-Mn eutectic alloy.

It can be also seen from Fig. 4 that an increase in solidification parameters leads to an increase in the HV values. The dependence of $\mathrm{HV}$ on eutectic spacing and growth rate were also determined as a order of growth rate by linear regression analysis and the relationship between them can be also
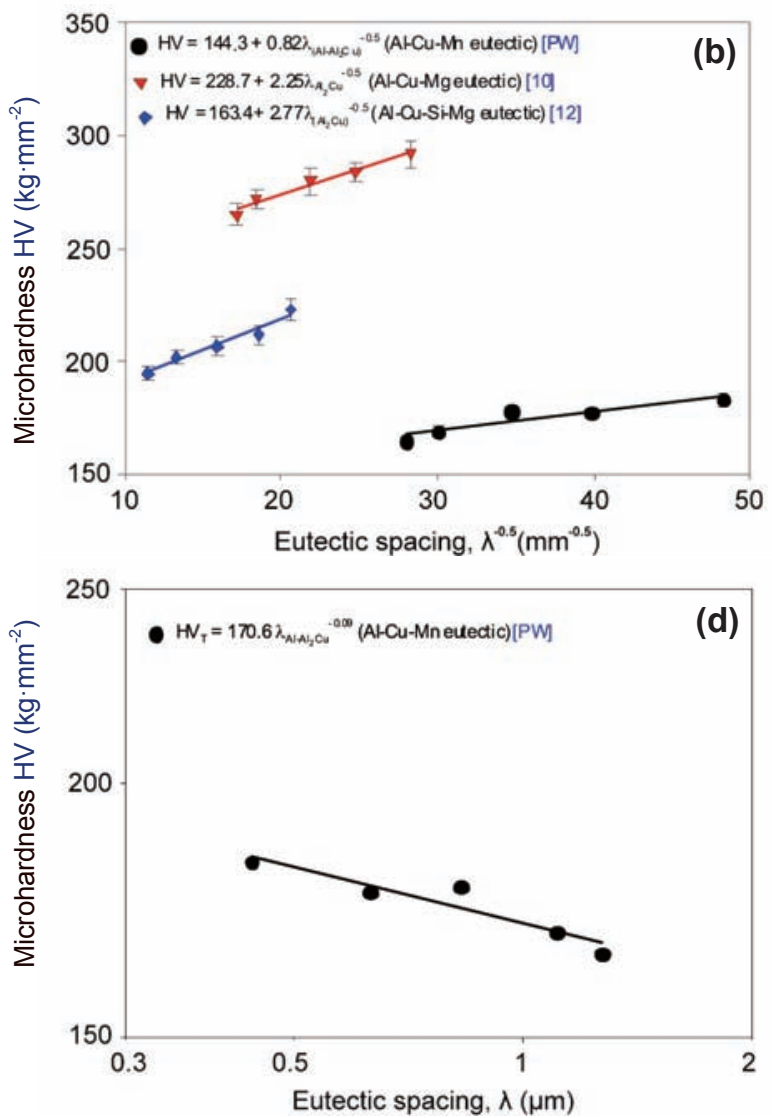

Fig. 4: Variations of microhardness with growth rates and eutectic spacing in Al-based multicomponent eutectic alloys at constant temperature gradients in the forms of: a, b) Hall-Petch type and c,d) exponential 
expressed as:

$$
\begin{aligned}
& \mathrm{HV}=k_{4}(V)^{a} \\
& \mathrm{HV}=k_{5}(\lambda)^{b}
\end{aligned}
$$

where $k_{4}$ and $k_{5}$ are constants and $a$ and $b$ are the exponent values relating to the growth rate. Experimental measured microhardness values for directionally solidified Al-Cu-Mn eutectic alloy are also given in Table 1. As shown in Table 1, when the solidification rates (from 8.4 to $166.2 \mu \mathrm{m} \cdot \mathrm{s}^{-1}$ ) are increased, the microhardness values (from 164.7 to 183.0 $\mathrm{kg} \cdot \mathrm{mm}^{-2}$ ) also increase. Figures $4(\mathrm{c})$ and (d) show the variation of $\mathrm{HV}$ as a function of eutectic spacing $(\lambda)$ and growth rate $(V)$ in the exponential form for Al-based multicomponent alloys ${ }^{[10,12]}$.

The exponential relationships between HV with $\lambda$ and $\mathrm{HV}$ with $V$ for directionally solidified Al-Cu-Mn eutectic alloy were determined to be:

$$
\begin{aligned}
& \mathrm{HV}=153.2(V)^{0.035} \\
& \mathrm{HV}=170.6(\lambda)^{-0.09}
\end{aligned}
$$

The value of exponent relating to growth rate $(0.035)$ obtained in the present work is about half of the value of the exponent relating to growth rate (0.07) obtained by Y. Kaygisız and N. Maraşl1 ${ }^{[21]}$ and the value of exponent relating to growth rate $(0.08)$ obtained by E. Çadırlı ${ }^{[22]}$ for directional solidified ternary Al-Si-Mg and binary Al-Cu eutectic alloys, respectively. The exponent value of eutectic spacing (0.09) obtained in the present work is lower than the values $(0.13-0.36)$ obtained by various researchers ${ }^{[23-27]}$ for different eutectic alloy systems under similar solidification conditions. The reason for this might be the existence of $\mathrm{Al}_{12} \mathrm{CuMn}_{2}$ intermetallic phase as an extra phase in the Al-Cu-Mn eutectic alloy.

The coefficient values of 153.2 and 170.6 for $\mathrm{Al}-\mathrm{Cu}-\mathrm{Mn}$ eutectic alloy are a little larger than the coefficient values of 119.9 for Al-Si-Mg ${ }^{[21]}$ eutectic alloys, obtained in previous works, but are considerably smaller than the coefficient values of 308.3 and 323.6 obtained for $\mathrm{Al}-\mathrm{Cu}-\mathrm{Mg}^{[10]}$ and $\mathrm{Al}-\mathrm{Cu}$ [22] eutectic alloys, respectively. The metastable $\mathrm{Al}_{2} \mathrm{Cu}$ and $\mathrm{Al}_{12} \mathrm{CuMn}_{2}$ intermetallic phases ensure a substantial effect of dispersion hardening in the course of decomposition of supersaturated solid solutions.

\section{Thermal analysis of $\mathrm{Al}-\mathrm{Cu}-\mathrm{Mn}$ alloy}

Differential thermal analysis (DTA) is an important technique for determining the temperatures of the phase transitions like melting point, solidification onset, re-crystallization onset, evaporation temperature in metallurgy and material science.

In the DTA technique, a test sample and an inert reference sample $\left(\mathrm{Al}_{2} \mathrm{O}_{3}, \mathrm{SiC}\right.$ or $\left.\mathrm{MgO}\right)$ for inorganic sample are heated and cooled under identical condition. The temperature difference between the test sample and reference sample is recorded. The differential temperature is then plotted either against time or against temperature. When a phase transition takes place in a sample that involves a release of heat, the temperature of the test sample rises temporarily above that of the reference sample, resulting in an exothermic peak. Conversely, a transition accompanied by absorption of heat reduces the temperature of the test sample compared to that of the reference sample, leading to an endothermic peak ${ }^{[28]}$.

In the present study, the $\mathrm{Al}-32.5 \mathrm{wt} . \% \mathrm{Cu}-0.6 \mathrm{wt} . \% \mathrm{Mn}$ alloy was heated at a heating rate of $10{ }^{\circ} \mathrm{C} \cdot \mathrm{min}^{-1}$ from $25^{\circ} \mathrm{C}$ to 900 ${ }^{\circ} \mathrm{C}$ by using a Exstar TG/DTA 7300 High Temperature Type model DTA and DTA curve obtained for Al-Cu-Mn eutectic alloy is shown in Fig. 5. A sharp peak is clearly observed for the melting process as shown in Fig. 5. As can be seen from Fig. 5, the melting temperature (eutectic temperature), melting onset temperature $\left(T_{\text {onset }}\right)$ and melting end temperature $\left(T_{\text {end }}\right)$ of Al-32.5wt.\%Cu-0.6wt.\%Mn alloy are $546.84{ }^{\circ} \mathrm{C}, 538.40{ }^{\circ} \mathrm{C}$ and $562.14{ }^{\circ} \mathrm{C}$, respectively. In Fig. 5 , the graph of temperature versus time also can be seen.

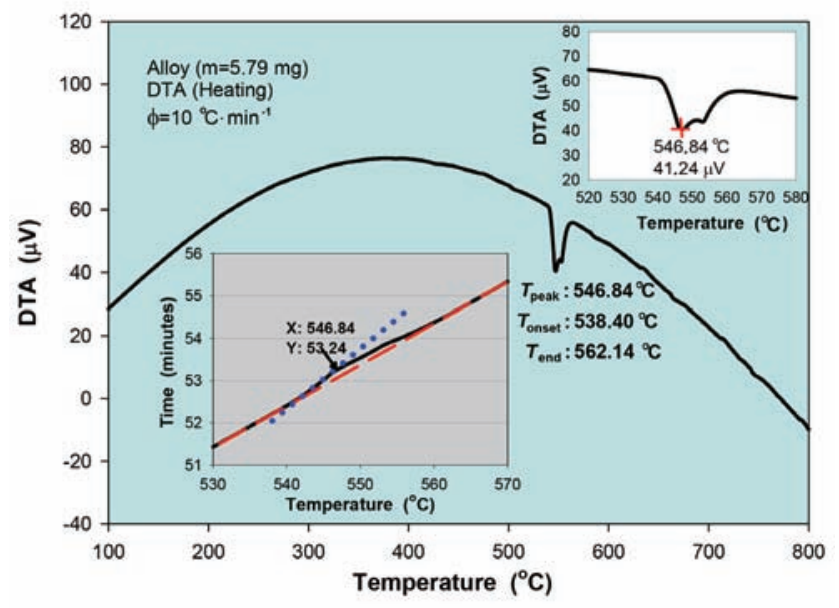

Fig. 5: DTA heating curve for Al-Cu-Mn eutectic alloy at a constant heating rate of $10^{\circ} \mathrm{C} \cdot \mathrm{min}^{-1}$

\section{Conclusions}

In this work, we were experimentally examined the dependency of eutectic spacings $(\lambda)$, and microhardness (HV) on growth rate $(V)$ at a constant temperature gradient $(G)$ in the Al32.5 wt. $\% \mathrm{Cu}-0.6 \mathrm{wt} . \% \mathrm{Mn}$ ternary eutectic alloy. The results obtained in the present work for the ternary $\mathrm{Al}-\mathrm{Cu}-\mathrm{Mn}$ eutectic alloy are summarized below:

(1) In the optical microscope images given in Fig. 1, eutectic microstructure consists of $\mathrm{Al}_{2} \mathrm{Cu}$ and $\mathrm{Al}_{12} \mathrm{CuMn}_{2}$ solid phases within an aluminum matrix $(\alpha-\mathrm{Al})$. $\mathrm{Al}$ and $\mathrm{Al}_{2} \mathrm{Cu}$ phases regularly grew up together, but $\mathrm{Al}_{12} \mathrm{CuMn}_{2}$ phases at irregular structure appear to grow randomly distributed between $\mathrm{Al}-\mathrm{Al}{ }_{2} \mathrm{Cu}$ eutectic phases.

(2) The $\mathrm{Al}-\mathrm{Al}_{2} \mathrm{Cu}$ binary eutectic lamellae structure was grown degenerate and $\mathrm{Al}_{12} \mathrm{CuMn}_{2}$ phase in the structure was observed to grow as scattered in the directionally solidified Al-Cu-Mn eutectic alloy at a low growth rate and constant temperature. When the growth rate in the directionally solidified Al-Cu-Mn eutectic alloy at a constant temperature was increased, the Al$\mathrm{Al}_{2} \mathrm{Cu}$ binary eutectic degenerate lamellae structure grew as colonies and the $\mathrm{Al}_{12} \mathrm{CuMn}_{2}$ phase in the structure concentrated at the boundary of the degenerated $\mathrm{Al}-\mathrm{Al}_{2} \mathrm{Cu}$ eutectic structure.

(3) In the SEM images given in Fig. 2, $\mathrm{Al}$ and $\mathrm{Al}_{2} \mathrm{Cu}$ 
phases were observed, but intermetallic $\mathrm{Al}_{12} \mathrm{CuMn}_{2}$ phase was not observed for directionally solidified Al-32.5wt.\%Cu0.6wt.\%Mn eutectic alloy. The reason why the $\mathrm{Al}_{12} \mathrm{CuMn}_{2}$ phase is not visible in the $\mathrm{Al}-32.5 \mathrm{wt} . \% \mathrm{Cu}-0.6 \mathrm{wt} . \% \mathrm{Mn}$ eutectic alloy system may be due to the fact that the atomic numbers of copper and manganese elements are close and the amount of manganese element $(0.6 \mathrm{wt} . \%)$ in the composition is very small.

(4) Based on the results of quantitative chemical composition analyses of the phases, the relationships between the eutectic spacings and growth rates were determined to be $\lambda_{\mathrm{Al}_{-\mathrm{Al}} \mathrm{Cu}}=3.02 \mathrm{~V}^{-0.36}$, by using linear regression,

(5) The dependency of HV on growth rates and eutectic spacings in the forms of Hall-Petch type and exponential were determined to be : $\mathrm{HV}=149.9+53.48(\mathrm{~V})^{0.25}$, $\mathrm{HV}=144.3+0.82\left(\lambda_{\mathrm{Al}_{-} \mathrm{Al}_{2} \mathrm{Cu}}\right)^{-0.50}, \mathrm{H} \mathrm{V}=153.2(V)^{0.035}$ a n d $\mathrm{HV}=170.6(\lambda)^{-0.09}$, respectively, by using linear regression analysis.

(6) The initial microindentation hardness values for equilibrated solid eutectic phases in equilibrium with liquid in this alloy system at its melting temperature were determined as 144.3 and $149.9 \mathrm{~kg} \cdot \mathrm{mm}^{-2}$. The value of microhardness increases from $164.7 \pm 1.2$ to $183.0 \pm 1.0 \mathrm{~kg} \cdot \mathrm{mm}^{-2}$ with increasing growth rate from 8.4 to $166.2 \mu \mathrm{m} \cdot \mathrm{s}^{-1}$. The bulk growth rate for $\mathrm{Al}-\mathrm{Al}_{2} \mathrm{Cu}$ phase in the Al-Cu-Mn eutectic alloy was $\lambda_{\mathrm{Al}-\mathrm{Al} 2 \mathrm{C}} \cdot V=25.38 \mu \mathrm{m}^{3} \cdot \mathrm{s}^{-1}$ by using the measured values of $\lambda_{\mathrm{Al}-\mathrm{Al} 2 \mathrm{Cu}}$ and $V$.

(7) The existence of $\mathrm{Al}_{12} \mathrm{CuMn}_{2}$ intermetallic phase in the ternary $\mathrm{Al}-\mathrm{Cu}-\mathrm{Mn}$ eutectic alloy causes the disparity of present results from the results obtained in previous works for Albased binary or ternary eutectic alloys.

(8) Based on the DTA thermal analysis, the melting temperature (eutectic temperature), melting onset temperature $\left(T_{\text {onset }}\right)$ and melting end temperature $\left(T_{\text {end }}\right)$ for Al-32.5wt.\% Cu$0.6 w t . \% \mathrm{Mn}$ alloy were found to be $546.84{ }^{\circ} \mathrm{C}, 538.40{ }^{\circ} \mathrm{C}$ and $562.14{ }^{\circ} \mathrm{C}$, respectively.

\section{References}

[1] Bhattacharya A, Kiran A, Karagadde S, et al. An enthalpy method for modeling eutectic solidification. Journal of Computation Physics, 2014, 262: 217-230.

[2] Kurz W, Fisher D J. Fundamentals of Solidification: Chapter 5. Switzerland. Trans Tech Publications, 1998.

[3] Orera V M, Pena J I, Larrea Á, et al. Engineered self-organized microstructures using directional solidification of eutectics. Ceramic Transaction, 2001, 225: 185-196.

[4] Moreto J A, Marino C E B, Bose Filho W W, et al. SVET, SKP and EIS study of the corrosion behaviour of high strength $\mathrm{Al}$ and AlLi alloys used in aircraft fabrication. Corrosion Science, 2014, 84: 30-41.

[5] Mondolfo L F. Aluminum Alloys-Structure and Properties. Butterworth, Boston, 1976: 424.

[6] Belov N A, Aksenov A A and Eskin D G. Iron in Aluminum Alloys: Impurity and Alloying Element. London: Taylor and Francis, 2002.

[7] Glazoff M, Zolotorevsky V, Belov N A. Casting Aluminum Alloys. 8st Edition, Elsevier Ltd, 2007.

[8] Drits M E, Kadaner E S, Padezhnova E M, et al. Phase Diagrams of Aluminum- and Magnesium-Based Systems. Ed. Abrikosov, N. Kh., Nauka, Moscow, 1977: 228.
[9] Ourdjini A, Liu J, Elliott R. Eutectic Spacing selection in Al-Cu System. Mater Science and Technology, 1994, 10: 312-318.

[10] Kaygısız Y and Maraşlı N. Microstructural, mechanical and electrical characterization of directionally solidified $\mathrm{Al}-\mathrm{Cu}-\mathrm{Mg}$ eutectic alloy. The Physics of Metals and Metallography. 2017, 118(4): 389-398.

[11] Çadırlı E, Ülgen A and Gündüz M. Directional Solidification of the Aluminium-Copper Eutectic Alloy. Materials Transactions, 1999, 40: 989-996.

[12] Kaygısız Y and Maraşı N. Directional solidification of Al-Cu-Si-Mg quaternary eutectic alloy. Journal of Alloys and Compounds, 2017, 721: 764-771.

[13] Gündüz M and Çadırlı E. Directional solidification of aluminiumcopper alloys. Material Science and Engineering A, 2002, 327: 167-185.

[14] Jackson K A and Hunt J D. Lamellar and eutectic growth. Transactions of the Metallurgical Society of AIME, 1966, 236: 1129-1142.

[15] Burden $\mathrm{M} \mathrm{H}$ and Jones H. Determination of Cooling Rate in SplatCooling from Scale of Microstructure. Journal of the Institute of Metals, 1970, 98: 249-252.

[16] Totten G E and MacKenzie D S. Handbook of Aluminum: Physical metallurgy and processes. New York: Marcel Dekker, Inc, 2003.

[17] Hall E O. The deformation and ageing of mild steel: III discussion of results. Proceedings of the Physical Society, Section B, 1951, 64: 747-753.

[18] Petch N J. The Cleavage strength of poly crystals. Journal of the Iron and Steel Institute, 1953, 174: 25-28.

[19] Hansen N. The effect on grain size and strain on the tensile stress of aluminum at room temperature. Acta Metallurgica, 1977, 25: 863-869.

[20] Embury J D, Lloyd D J and Ramachandran T R. Strengthening mechanisms in aluminum alloys. Treatise on Materials Science and Technology, 1989, 31: 579-601.

[21] Kaygısız Y and Maraşlı N. Microstructural, mechanical and electrical characterization of directionally solidified Al-Si-Mg eutectic alloy. Journal of Alloys and Compounds, 2015, 618: 197-203.

[22] Emin Çadırlı. Effect of Solidification Parameters on Mechanical Properties of Directionally Solidified Al-Rich Al-Cu Alloys. Metals and Materials International, 2013, 19(3): 411-422.

[23] Fan J, Li X, Su Y, ET AL. Effect of Growth Rate On Microstructure Parameters and Microhardness in Directionally Solidified Ti-49Al Alloy. Materials and Designing, 2012, 34: 552-558.

[24] Böyük U, Maraşli N, Çadırlı E, et al. Variations Of Microhardness with Solidification Parameters and Electrical Resistivity with Temperature for Al-Cu-Ag Eutectic Alloy. Current Applıed Physıcs, 2012, 12: 7-10.

[25] Fan J, Li X, Su Y, et al. Dependency of Microhardness On Solidification Processing Parameters and Microstructure Characteristics in the Directionally Solidified Ti-46Al-0.5W-0.5Si Alloy. Journal of Alloys and Compounds, 2010, 504: 60-64.

[26] Kaya H, Böyük U, Çadirli E, et al. Influence of growth rate on microstructure, microhardness and electrical resistivity of directionally solidified Al-7 wt.\% Ni hypo-eutectic alloy. Metals and Materıals Internatıonal, 2013, 19: 39-44.

[27] Engin S, Büyük $U$, Maraşlı N. The effects of microstructure and growth rate on microhardness, tensile strength, and electrical resistivity for directionally solidified Al-Ni-Fe alloys. Journal of Alloys and Compounds, 2016, 660: 23-31.

[28 Du Y, Liu S, Zhang L, et al. An overview on phase equilibria and thermodynamic modeling in multicomponent $A$ l alloys: Focusing on the Al-Cu-Fe-Mg-Mn-Ni-Si-Zn system. CALPHAD: Computer Coupling of Phase Diagrams and Thermochemistry, 2011, 35: 427-445. 